\title{
Patents found on the Accer Aspire U27 product, the all-in-one Desktop \\ Khoiria Zulhijah 155100040
}

Fakultas Komputer, 448757177

khoiriazulhijah.student@umitra.ac.id

\begin{abstract}
The Accer was founded by the main store Stan Shih and his wife Carolyn Yeh, as well as a group of five other people with a company called Multitech in 1976, headquartered in the city of Hsinchu, Taiwan. The company began with eleven employees and US \$25,000 in capital. Initially, the company was engaged in electronic component distributors and as a consultant for the use of microprocessor technology.

The Multitech company produces Micro-Professor MPF-I products, then two Apple II clones. The last is the product Microprofessor II and III and then Accer joined IBM PC, and in 1987 became a significant PC manufacturer and the company Multitech changed its name to Accer.

In 2005, Accer employed around 7,800 people worldwide. Revenues rose from US \$ 4.9 billion in 2003, to US \$ 11.33 billion in 2006 .

Accer a few days ago officially presented 2 of the latest all-in-one desktop products to Indonesia, one of which is the Accer Aspire U27, this all-in-one desktop computer has an elegant design, touch screen and attractive multimedia features.
\end{abstract}

Keywords: Accer, Multitech, Accer Aspire U27 All-in-one 


\section{A. INTRODUCTION}

Product patents from Accer namely Accer Aspire U27 launched by Accer on March 14, 2018 this product has an elegant and attractive design in accordance with current trends. The all-in-one desktop has a 27-inch Full HD screen that also supports touchscreen with multitouch up to 10 fingers. In addition, the elegant design is also supported by a V-shaped stand that is modern and spacesaving.

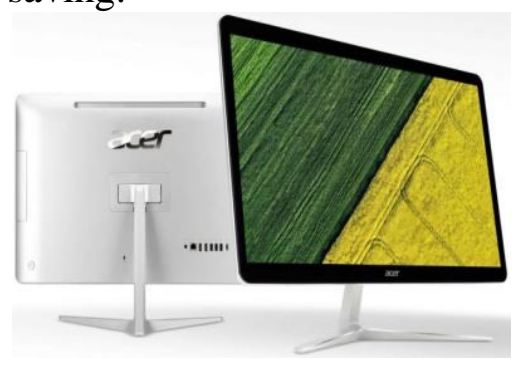

The Aspire U27 Design Accer is made of metal and plastic, but both materials have identical metal layers, so you won't pay attention to the different materials used in the contour.

The entire system is held above an aluminum stand, which has adjustable Y-shaped legs. A stand is one part of the system that needs to be assembled after unboxing, but the base attaches to the holder with a simple finger screw, so you don't even need a screwdriver.

The Accer Aspire U27 makes things quieter by removing the cooling fan that most systems use. Instead, the all-in-one is equipped with a fanless pipe cooling system, called Liquid Loop, which makes everything cool with a closed cooling system.

When the liquid circulates through a heat pipe, the liquid evaporates under heat, condenses when it flows through the closed loop, and returns to do it again, dissipating heat when spinning. The result is a system that does not need a cooling fan, and runs quieter than a competing system.

Then the Accer Aspire U27 features multimedia features with the ExaColor Accer feature to produce accurate colors.

Then to produce quality sound, this all-in-one desktop also has a subwoofer that is behind the screen.

The Acer Aspire U27 uses a 7th generation Intel Core processor, the Core i7 $7500 \mathrm{U}$. Then this device has $8 \mathrm{~GB}$ of DDR4 RAM and 2TB of HDD storage.

To improve performance

The HDD, the Acer Aspire U27 also has an Intel Optane SSD as a caching solution.

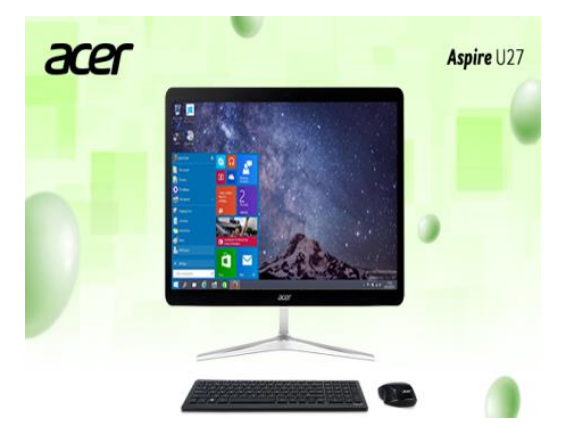


Then the Acer Aspire U27 also uses a cooling system with Acer LiquidLoop technology. This cooling system does not use a fan so it does not cause noise and reduces the amount of dust entering it.

As a result, PC performance can be smoother, using energy more efficiently and the product usage period will tend to be more durable.

The greatness of the Accer Aspire U27 is not only on the engine factor, but also on the security aspects. No need to fear data and documents will be leaked or stolen by others, because the Accer Aspire U27 carries an infrared camera (IR) based security system on its PC device, to login. You only need to show your face in front of the PC screen. The IR Camera system on the Accer Aspire U27 is able to provide highquality information needed for biometrics. Later, this IR Camera will activate Windows Hello so you can just log in by showing your face.

Enhancing Image and Face Quality for those who like playing games, listening to music while working, or playing movies via $\mathrm{PC}$, the Accer Aspire U27 can meet your needs through its Subwoofer technology.

With a longer sound tube, the range of sound frequencies can reach up to $250 \mathrm{~Hz}$ creating bass sounds that are deeper and more powerful.
The powerful sound quality is also offset by the appearance of increasingly clear and sharp colors. All thanks to Accer Exacolor "TM, technology that is able to correct color and adjust saturation and contrast on the screen, both for content that can be displayed from PC internet data or via an HDMI connection.

Keyboard and Mouse

The Aspire U27 comes with a wireless keyboard and mouse that shares one small wireless USB adapter. They are suitable, with the construction of black plastic that contrasts with the glossy black piano with a simple matte touch on the keyboard keys and the parts of the mouse that you hold.

The keyboard is set at a comfortable angle, with square box buttons, including a row of function keys half the size along the top row. The depth of the key travel is on the shallow side (1.8 millimeters), but it will be done for light use. The mouse is a basic ambidextrous optical mouse. Plastic construction doesn't feel very important, but it will make you survive.

\section{Accer Aspire U27 SPECIFICATIONS}

CPU: 7th Gen Intel CPUs

Operating system: Windows 10 Wireless: 802.11ac2x2 MIMO

Facial log-in: IR Camera \& Windows Hello Compliant RAM: 8GB

Diplay size: $68.6 \mathrm{~cm}$ 
Resolution: 1920x1080

Cooling: Fan -less Liquid

Cooling

USB 3.0Ports: 1

USB 2.0Ports: 3

HDMI Ports: 2

Network: GB-Lan

Accer Aspire U27 saat ini telah tersedia di pasaran Indonesia dengan harga Rp22.999.000. selama masa promosi yang akan berakhir pada 31 Maret 2018, Accer akan memberikan bonus berupa headset gaming predator untuk setiap pembelian Accer Aspire U27

\section{B. CONCLUSION}

The conclusion

1. Patents in each product have patent rights, namely inventors of their inventions in the field of technology, with a certain length of time or give approval to others to carry it out.

2. Inventor is someone who alone or several people who jointly implement ideas that want to produce an invention or product.

3. The patent holder is someone who is the patent owner or the party who receives the right from the patent owner.

4. What should be avoided before the application of a patent is submitted, namely to publish in general the results of research or discovery within a period of more than 6 (six) months before the patent application is submitted

5. 3 ways of disclosing a research / discovery result can occur:

1. Decomposition of techniques with published writings.
2. Decomposition of the product or how to use it in public

3. Product exhibition, which is in the form of an international exhibition in Indonesia or abroad that is official or recognized as official.

6. What is meant by claim the most important part of an invention (invention) that is requested for protection, and in the claim disclosed all the technical advantages of the invention

The Accer Aspire U27 will change everything you know about previous PC devices. Whatever your needs or preferences, from starting to work to playing games, Accer Aspire U27 is ready to be the PC that will faithfully accompany you.

\section{ACKNOWLEDGEMENT} University Of Indonesia University Of Mitra Indonesia Telkom University University Of Mellbourne Saitama University

\section{REFERENCE(Based ISO 690 )}

A. S. Putra And O. M. Febriani, "Knowledge Management Online Application In Pdam Lampung Province," In Prosiding International Conference On Information Technology And Business (Icitb), 2018, Pp. 181-187.

[2] A. S. Putra, O. M. Febriani, And B. Bachry, "Implementasi Genetic Fuzzy System Untuk 
Mengidentifikasi Hasil Curian Kendaraan Bermotor Di Polda Lampung," J. Sist. Inf. Dan Manaj. Basis Data, Vol. 1, No. 1, Pp. 21-30, 2018.

[3] O. M. Febriani And A. S. Putra, "Sistem Informasi Monitoring Inventori Barang Pada Balai Riset Standardisasi Industri Bandar Lampung," J. Inform., Vol. 13, No. 1, Pp. 90-98, 2014.

[4] Putra, Arie Setya. "2018 Artikel Struktur Data, Audit Dan Jaringan Komputer." (2018).

[5] Putra, A. S. (2018, July 17). Paperplain Fundamental Create Application With Borland Delphi 7.0 University Of Mitra Indonesia. Retrieved From Osf.Io/Pbrn9.

\section{E. REFERENCE (Based APA $)$}

Putra, A. S., Aryanti, D. R., \& Hartati, I. (2018, November). Metode SAW (Simple Additive Weighting) sebagai Sistem Pendukung Keputusan Guru Berprestasi (Studi Kasus: SMK Global Surya). In Prosiding Seminar Nasional Darmajaya (Vol. 1, No. 1, pp. 85-97).

Sari, D. P., Febriani, O. M., \& Putra, A. S. (2018, November). Perancangan Sistem Informasi SDM Berprestasi pada SD Global Surya. In Prosiding Seminar Nasional Darmajaya (Vol. 1, No. 1, pp. 289-294).

Putra, A. S. (2018). Paperplain: Execution Fundamental Create Application With Borland Delphi 7.0 University Of Mitra Indonesia.
Putra, A. S., Sukri, H., \& Zuhri, K. Sistem Monitoring Realtime Jaringan Irigasi Desa (JIDES) Dengan Konsep Jaringan Sensor Nirkabel. IJEIS (Indonesian Journal of Electronics and Instrumentation Systems), 8(2), 221232.

Darmawan, A., Yuliawati, D., Marcella, O., \& Firmandala, R. (2016). Sistem Absensi dan Pelaporan Berbasis Fingerprint dan SMS Gateway. EXPLORE, 7(1).

Febriani, O. M., Wahyuni, T., \& Yusuf, S. (2017). DESIGN OF WEBSITE-BASED INFORMATION SYSTEM FOR EDOCUMENT ADMINISTRASI IN THE COMMUNITY SERVICE UNIT (A Case Study at Rajabasa District). INTERNATIONAL JOURNAL OF COMPUTERS \& TECHNOLOGY, 16(7), 7010-7020.

Febriani, O. M., \& Wahyuni, T. (2017, October). PERANCANGAN SISTEM E-DOCUMENT ADMINISTRASI LOGBOOK PENELITIAN PADA UNIT LAYANAN DI BANDAR LAMPUNG. In Prosiding Seminar Nasional Darmajaya (Vol. 1, No. 1, pp. 187-194).

Febriani, O. M., \& Permadi, A. B. (2017). Implementasi Sistem Aplikasi Data Bimbingan dan Pelanggaran Siswa pada Sekolah Menengah Atas di Lampung Tengah dengan Metode Analisis dan Desain Sistem Terdistribusi (SSAD). EXPERT, 7(1).

Febriani, O. M., \& Ambarwati, L. (2015). PERANCANGAN APLIKASI 
PENGOLAHAN DATA

PENJUALAN UKM KELANTING

KHAS TELO DESA SIDOHARJO

KECAMATAN JATI AGUNG

KABUPATEN LAMPUNG

SELATAN. Jurnal Teknologi

Informasi dan Bisnis Pengabdian

Masyarakat Darmajaya, 1(1), 77-95.

Febriani, O. M. (2015). Rancang Bangun Aplikasi Ecommercemenggunakan Freewebstore pada UKM Kelanting di Desa Sidoharjo Lampung Selatan. Prosiding Sembistek 2014, 1(02), 446-458. 